\title{
Experimental Investigation of Bed Joint Reinforcement Corrosion in Masonry Mortars
}

\author{
Alexandros Stathatos' ${ }^{1}$, Angeliki Zacharopoulou ${ }^{2}$, Georgios Batis ${ }^{2}$, Elisavet Vintzileou ${ }^{1}$ \\ ${ }^{1}$ Department of Structural Engineering, School of Civil Engineering, National Technical University of Athens \\ (NTUA), Athens, Greece \\ ${ }^{2}$ Department of Materials Science and Engineering, School of Chemical Engineering, National Technical \\ University of Athens (NTUA), Athens, Greece \\ Email: aggeliki.zaxaropoulou@gmail.com
}

Received 18 December 2015; accepted 6 March 2016; published 9 March 2016

Copyright (C) 2016 by authors and Scientific Research Publishing Inc.

This work is licensed under the Creative Commons Attribution International License (CC BY).

http://creativecommons.org/licenses/by/4.0/

c) (i) Open Access

\begin{abstract}
The paper investigates the behaviour against corrosion offered by seven masonry mortar compositions to the reinforcement placed in masonry bed joints. Durability protection was evaluated on the basis of four criteria: carbonation area of the specimens, mass loss of steel, electrochemical potential and presence of chloride ions. Tests were performed against two corrosive environments, with and without chloride ions, and were carried out for three periods: three, six and thirty three months. Two types of steel were used, plain steel and galvanized steel. Moreover, the steel protective action of a corrosion inhibitor, sodium nitrite, was examined. A qualitative comparison approach against prototype concrete-like mortars was used. The results showed that the selected masonry mortars did not exhibit similar properties against corrosion to those of concrete and that the addition of sodium nitrite decrease of the corrosion rate only $5 \%-20 \%$ did not meaningfully improve durability properties. Nevertheless, the addition of lime in small quantities did not have a negative impact on the mortars' durability characteristics, e.g. the same average corrosion rate.
\end{abstract}

\section{Keywords}

Corrosion, Masonry Mortar, Concrete, Building

\section{Introduction}

Reinforcing bars are incorporated in masonry structures in order to improve their behaviour under service condi-

How to cite this paper: Stathatos, A., Zacharopoulou, A., Batis, G. and Vintzileou, E. (2016) Experimental Investigation of Bed Joint Reinforcement Corrosion in Masonry Mortars. Open Journal of Metal, 6, 1-12.

http://dx.doi.org/10.4236/ojmetal.2016.61001 
tions and mainly against seismic action [1]-[4]. Reinforcement in masonry is placed in the horizontal mortar joints (horizontal reinforcement) and in special holes made out in vertically perforated clay or concrete units (vertical reinforcement); these holes are filled with grout. In the case of the horizontal reinforcement, the thickness of the overlaying mortar is particularly small; even when the thickness of the joint is $15 \mathrm{~mm}$ (the maximum allowed according to EC8 [5]) the overlaying mortar thickness of a $5 \mathrm{~mm}$ steel bar is only $5 \mathrm{~mm}$. On the contrary, the vertical reinforcement is usually covered with adequate mortar. Therefore, there is higher need to carefully select the bed joint mortar composition, rather than the composition of the vertical holes' grout.

But how does steel covered with mortar corrode? In the initial stages, mortar and grout offer to the reinforcement a passive protection thanks to the alkali environment due to the presence of calcium hydroxide $(\mathrm{pH}$ value about 13.5). A thin protective oxide layer is then formed, strongly attached at the surface of the bars. $\mathrm{As}^{\mathrm{CO}_{2}}$ of the environment penetrates in the joints and under the simultaneous presence of appropriate moisture content mortar carbonates and the $\mathrm{pH}$ value sinks. The protective layer is destroyed and the electrochemical corrosive procedure (for the realisation of which the simultaneous presence of $\mathrm{O}_{2}$ and $\mathrm{H}_{2} \mathrm{O}$ is required) initiates. De-passivation of the bars can also be obtained if chloride ions under the simultaneous presence of $\mathrm{O}_{2}$ and $\mathrm{H}_{2} \mathrm{O}$ penetrate into the structure [6] [7]. If $\mathrm{Cl}^{-}$to $\mathrm{OH}^{-}$ions ratio becomes greater than a threshold value, corrosion may initiate. $\mathrm{Cl}^{-}$may be present in the environment at marine areas or in mortar and grout additives or even in the mix water [8].

The rate of realisation of the corrosive procedure depends on the rate of penetration of the aggressive environmental agents through a capillary action and through the minor cracks of the mortar (or grout). This rate is mainly affected by the permeability of the mortar mix which is conditioned by several factors, i.e. the chemical composition of its constituent materials, the water to binder ratio used, its porosity, its compaction and curing conditions, and finally the presence of initial minor cracks [8] [9].

Current research is trying to improve the durability of masonry mortars with various additives e.g. metakaolin, bentonite, linseed oil [10] [11].

Due to high water to binder ratios which are usually found in masonry mortars, it is thought that mortars cannot simultaneously offer adequate workability and mechanical and durability characteristics. However, this is perhaps due to improper selection of the constituent materials and to unsuccessful compositions of the mortars examined. Based on previous experience on durability behaviour of concrete and light concrete [12] [13], it is the authors' opinion that mortars with adequate workability/mechanical characteristics which simultaneously exhibit durability properties similar to that of concrete, can be prepared.

\section{Experimental Procedures}

Seven compositions (see Table 1), 3 cement mortars (M1, M2, M3) and 4 lime-cement mortars (ML1, ML2, ML3 and ML4), complying with the requirements of EN 998-2 [14] and the European codes EC6 [15] and EC8 [5] were selected. The first two cement mortars (M1, M2) constitute the reference mortars with which test comparisons were made as they have similar compositions to those of regular concrete, and therefore, are considered to have similar durability performance. Lime-cement mortars were investigated in order to check whether the presence of hydrated lime would enhance or not durability properties due to the excessive quantity of $\mathrm{Ca}(\mathrm{OH})_{2}$ in the mix [16]. It is important to note that mortars M3, ML1, ML2, ML3 and ML4 have different proportions of sand and water when compared to their cement content, but have identical proportions when compared to their cement plus lime content.

All mortar compositions exhibited a certain level of workability, complying with the requirements of EN 1015-2 [17], i.e. $175 \pm 10 \mathrm{~mm}$ slump. It should be noted that in order to obtain water to binder ratios as low as possible, a super plasticizer (Daracem 140, i.e. a mixture based on soulfom polymers dissolvable in water) was added in all cement mixes in a dosage of $1.5 \%$ per cement weight.

For the preparation of the mixes, Portland cement (with up to 55\% of pozzolanic constituents) was employed, referred as Portland cement IV $32.5 \mathrm{~N}$, according to EN 197-1 [18]. Hydrated lime in dry and in paste form (with 55\% free water) and marble crushed sand (with maximum grain diameter of $4 \mathrm{~mm}$ ) were used.

For the estimation of the mechanical characteristics of mortars, three prismatic specimens were tested at the age of 28 days against flexure and consequently against compression according to prEn1015-11 [19]. Test results are given in Table 2. Furthermore, for each mortar composition a prismatic specimen was prepared to be used for the measurement of the total porosity, the mean pore radius and the dry bulk density of the mortars at 
Table 1. Mortars and material proportions in the dry mix.

\begin{tabular}{|c|c|c|c|c|c|c|c|c|}
\hline \multirow{2}{*}{ Mortar } & \multicolumn{8}{|c|}{ Material quantities corresponding to $10 \mathrm{~kg}$ of dry mix } \\
\hline & $\begin{array}{c}\text { Cement } \\
\text { (kg) }\end{array}$ & $\begin{array}{c}\text { Lime } \\
\text { (kg) }\end{array}$ & $\begin{array}{c}\text { Sand } \\
(\mathrm{kg})\end{array}$ & $\begin{array}{l}\text { Water } \\
\text { (kg) }\end{array}$ & $\begin{array}{l}\text { Plasticizer } \\
\text { (kg) }\end{array}$ & $\begin{array}{l}\text { Sodium nitrite } \\
\text { (kg) }\end{array}$ & $\begin{array}{c}\text { Water to binder } \\
\text { ratio }\end{array}$ & $\begin{array}{l}\text { Type of } \\
\text { lime }\end{array}$ \\
\hline M1 & 2.50 & & 7.50 & 1.23 & 0.025 & & 0.50 & \\
\hline M2 & 2.00 & & 8.00 & 1.18 & 0.020 & & 0.60 & \\
\hline M3 & 1.67 & & 8.35 & 1.57 & 0.017 & & 0.95 & \\
\hline М3 $\alpha$ & 1.67 & & 8.35 & 1.51 & 0.017 & 0.058 & 0.95 & \\
\hline ML1 & 1.38 & 0.36 & 8.28 & 1.31 & & & 0.95 & Paste \\
\hline ML1 $\alpha$ & 1.38 & 0.36 & 8.28 & 1.26 & & 0.048 & 0.95 & Paste \\
\hline ML2 & 1.59 & 0.16 & 8.27 & 1.51 & & & 0.95 & Paste \\
\hline ML2 $\alpha$ & 1.59 & 0.16 & 8.27 & 1.45 & & 0.056 & 0.95 & Paste \\
\hline ML3 & 1.38 & 0.36 & 8.28 & 1.31 & & & 0.95 & Dry \\
\hline $\operatorname{ML3} \alpha$ & 1.38 & 0.36 & 8.28 & 1.26 & & 0.048 & 0.95 & Dry \\
\hline ML4 & 1.59 & 0.16 & 8.27 & 1.51 & & & 0.95 & Dry \\
\hline ML4 $\alpha$ & 1.59 & 0.16 & 8.27 & 1.45 & & 0.056 & 0.95 & Dry \\
\hline
\end{tabular}

Table 2. Mean flexural and compressive strength of mortars during 28 days.

\begin{tabular}{ccc}
\hline Mortar & Mean flexural strength (MPa) & Mean compressive strength (MPa) \\
M1 & 6.4 & 45.2 \\
M2 & 6.1 & 42.8 \\
M3 & 4.0 & 15.4 \\
M3 $\alpha$ & 3.9 & 18.9 \\
ML1 & 3.4 & 20.0 \\
ML1 $\alpha$ & 3.7 & 20.0 \\
ML2 & 4.3 & 21.9 \\
ML2 $\alpha$ & 4.4 & 23.6 \\
ML3 & 2.4 & 13.3 \\
ML3 $\alpha$ & 2.5 & 13.0 \\
ML4 & 3.8 & 18.7 \\
ML4 $\alpha$ & 3.8 & 18.0 \\
\hline
\end{tabular}

the age of 6 months. The measurements were carried out on small portions of these specimens by means of a mercurus porosimeter Milestone 2000 of Carlo Erba. Tests results are depicted in Table 3.

Durability protection behaviour of the mortars was evaluated on the basis of four criteria: 1) carbonation area of the specimens, 2) open circuit potential, 3) mass loss of steel and 4) presence of $\mathrm{Cl}^{-}$.

To this purpose, small cylindrical specimens of a diameter of $40 \mathrm{~mm}$ and of a height of $100 \mathrm{~mm}$ with embedded reinforcement of a diameter of $5 \mathrm{~mm}$ were prepared. The reinforcement protruded 20 mm of the specimen's upper surface. Specimens were partially immersed in de-ionized water and in de-ionized water with $3.5 \% \mathrm{NaCl}$. These conditions correspond to exposure classes MX2 and MX4 of European code EC6 [15]. The upper surface of the specimen as well as the protruding bar of each specimen were covered with a thin layer of epoxy resin in 
order to avoid the corrosion of the unprotected surface of the steel bar. The characteristics of the specimens are shown in Figure 1.

Carbonation area of the specimens and mass loss of steel were measured at 3, 6 and 33 months; whereas the measurements of the electrochemical potential were carried out throughout the whole period. Presence of $\mathrm{Cl}^{-}$ was measured at the end of the 33 month period. For each mortar composition, each type of steel and each corrosion environment nine specimens were constructed; three specimens for the 3 months, three specimens for the 6 months and three specimens for 33 months (see Table 4).

Table 3. Mean pore radius, total porosity (\%) and dry bulk density $\left(\mathrm{kg} / \mathrm{m}^{3}\right)$ of each mortar.

\begin{tabular}{ccccccccccccc}
\hline Mortar & M1 & M2 & M3 & M3 $\boldsymbol{\alpha}$ & ML1 & ML1 $\boldsymbol{\alpha}$ & ML2 & ML2 $\boldsymbol{\alpha}$ & ML3 & ML3 $\boldsymbol{M L 4}$ & ML4 $\boldsymbol{\alpha}$ \\
\hline Average pore radius $(\mathbf{\AA})$ & 0.211 & 0.223 & 0.78 & 0.783 & 0.432 & 0.538 & 0.538 & 0.562 & 0.407 & 0.432 & 0.432 & 0.538 \\
Total porosity (\%) & 15.01 & 15.11 & 18.02 & 18.69 & 23.66 & 23.16 & 20.26 & 21.67 & 18.45 & 20.86 & 21.47 & 19.96 \\
Dry bulk density $\left(\mathbf{k g} / \mathbf{m}^{\mathbf{3}}\right)$ & 2.20 & 2.20 & 2.17 & 2.15 & 2.03 & 2.01 & 2.11 & 2.09 & 2.13 & 2.09 & 2.06 & 2.11 \\
\hline
\end{tabular}

Table 4. Number of corrosion specimens according to the considered parameters.

\begin{tabular}{|c|c|c|c|c|c|c|c|c|c|}
\hline \multirow{2}{*}{ Mortar } & \multicolumn{3}{|c|}{$\begin{array}{c}\text { Corrosive environment MX2, } \\
\text { plain steel }\end{array}$} & \multicolumn{3}{|c|}{$\begin{array}{c}\text { Corrosive environment MX4, } \\
\text { plain steel }\end{array}$} & \multicolumn{3}{|c|}{$\begin{array}{l}\text { Corrosive environment MX4, } \\
\text { zinc coated steel }\end{array}$} \\
\hline & 3 months & 6 months & 33 months & 3 months & 6 months & 33 months & 3 months & 6 months & 33 months \\
\hline M1 & 3 & 3 & 3 & 3 & 3 & 3 & 3 & 3 & 3 \\
\hline M2 & 3 & 3 & 3 & 3 & 3 & 3 & 3 & 3 & 3 \\
\hline M3 & 3 & 3 & 3 & 3 & 3 & 3 & 3 & 3 & 3 \\
\hline $\mathbf{M} 3 \alpha$ & & & & 3 & 3 & 3 & & & \\
\hline ML1 & 3 & 3 & 3 & 3 & 3 & 3 & 3 & 3 & 3 \\
\hline $\operatorname{ML1} \alpha$ & & & & 3 & 3 & 3 & & & \\
\hline ML2 & 3 & 3 & 3 & 3 & 3 & 3 & 3 & 3 & 3 \\
\hline ML2 $\alpha$ & & & & 3 & 3 & 3 & & & \\
\hline ML3 & 3 & 3 & 3 & 3 & 3 & 3 & 3 & 3 & 3 \\
\hline ML3 $\alpha$ & & & & 3 & 3 & 3 & & & \\
\hline ML4 & 3 & 3 & 3 & 3 & 3 & 3 & 3 & 3 & 3 \\
\hline ML4 $\alpha$ & & & & 3 & 3 & 3 & & & \\
\hline
\end{tabular}

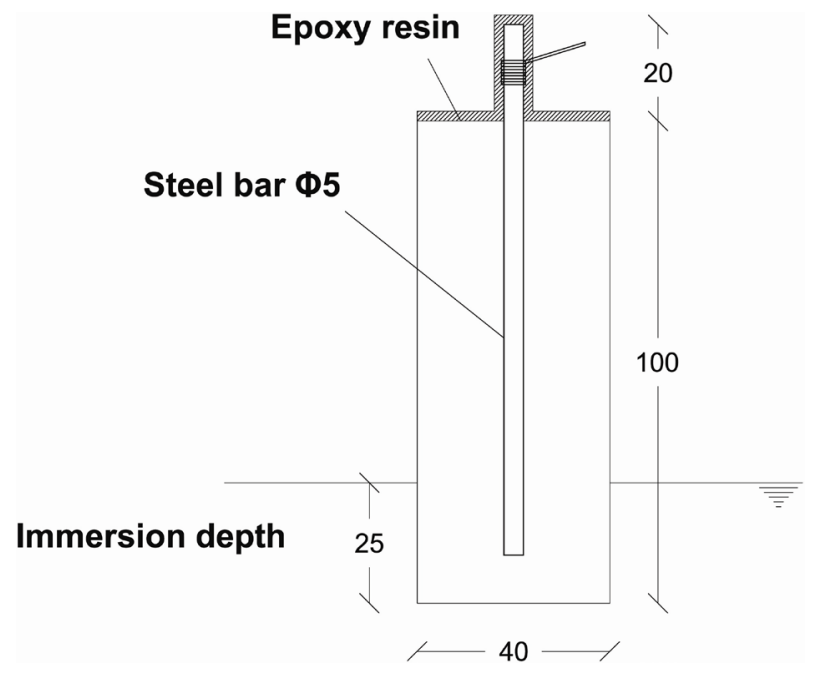

Figure 1. Specimen characteristics (dimensions in $\mathrm{mm}$ ). 
The determination of chloride was made according to the method Mohr.

The Mohr method uses chromate ions as an indicator in the titration of chloride ions with a silver nitrate standard solution. After all the chloride has been precipitated as white silver chloride, the first excess of titrant results in the formation of a silver chromate precipitate, which signals the end point.

By knowing the stoichiometry and moles consumed at the end point, the amount of chloride in an unknown sample can be determined.

It is important to note that the specimens made with corrosion accelerators, because the samples were half immersed in $3.5 \% \mathrm{NaCl}$.

The total number of the specimens is 234. For the medium corrosion environment MX2 plain steel bars were used, whereas for the intensively corrosion environment MX4 both plain and galvanized steel bars were used. The steel protection action of a corrosion inhibitor, sodium nitrite, was examined in the case of MX4 environment with plain steel bars.

\section{Test Results}

\subsection{Carbonation Area of the Specimens}

After the end of each period of time, specimens are removed from each corrosive environment and then they are split into two pieces parallel to steel bar axis. The carbonation area of each specimen is determined on the surface of each specimen by means of a phenolphthalein indicator; the carbonated surface of the specimen remains uncolored whereas the carbonation area is dyed purple. The carbonation depth is increased from bottom to top; it is approximately zero at the immersed area of the specimen and takes its higher value at the top (see Figure 2; carbonation increases at higher $\mathrm{CO}_{2}$ presence and more dry conditions, which both tend to happen the farther up the immersion depth of the specimen). Figure 3 and Figure 4 depict the mean values of the carbonation depth for each type of mortar at 3, 6 and 33 months and corrosion environment MX2 and MX4 respectively.

The results indicate that carbonation depth increases through time in all cases, but that the carbonation area has not reached the reinforcement in any case. For the same mortar compositions and time elapsed, carbonation depth is $5 \%-20 \%$ higher in the case of MX4 environment. As expected, the two reference mortars M1 and M2 exhibit the lowest carbonation depth values; in the case of MX2 environment carbonation depths of the prototype mortars is $20 \%$ - $40 \%$ lower than those of M3, ML1, ML2, ML3, ML4 mortars, whereas in the case of MX4 environment values are 30\% - 50\% lower. Mortars M3, ML1, ML2, ML3 and ML4 exhibit similar carbonation depth in both environments; differences are in the magnitude of $\pm 10 \%$. The addition of sodium nitrite does lower carbonation but not materially; mortars with corrosion inhibitor exhibit 5\% - 10\% lower carbonation depths than the respective inhibitor-free compositions.

\subsection{Open Circuit Potential}

The open circuit potential of the steel bars is measured during exposure of the specimens, at intervals of one week for the first three months of exposure, and once a month or two afterwards, by means of saturated calomel

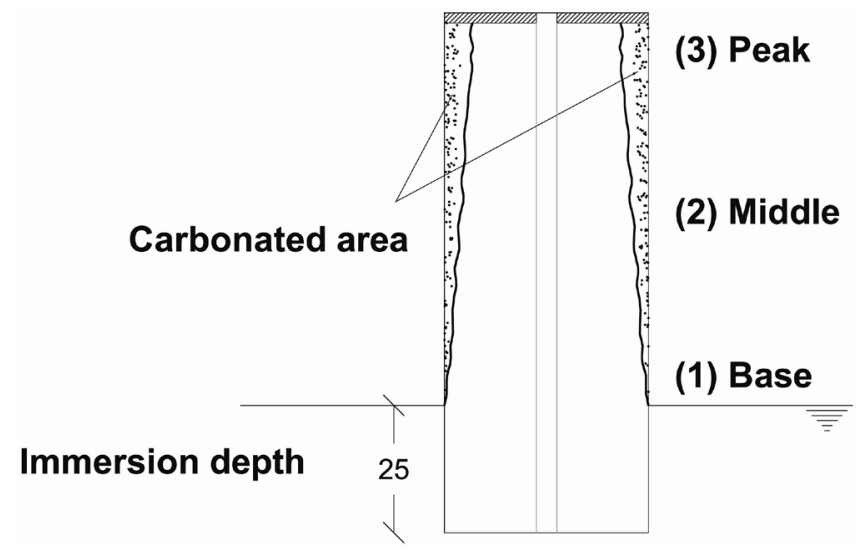

Figure 2. Carbonation area of the specimens (dimensions in $\mathrm{mm}$ ). 


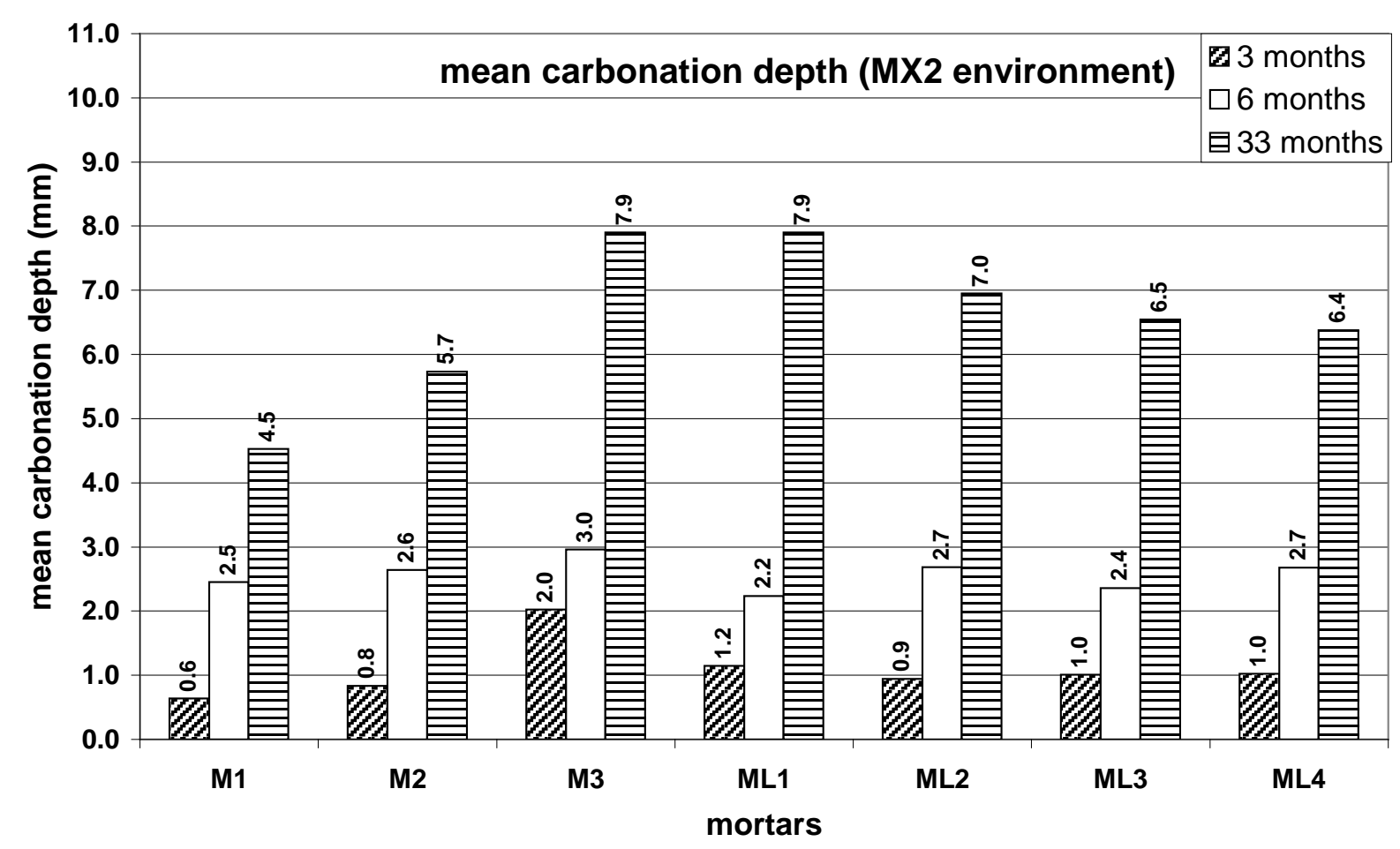

Figure 3. Mean carbonation depth at MX2 environment.

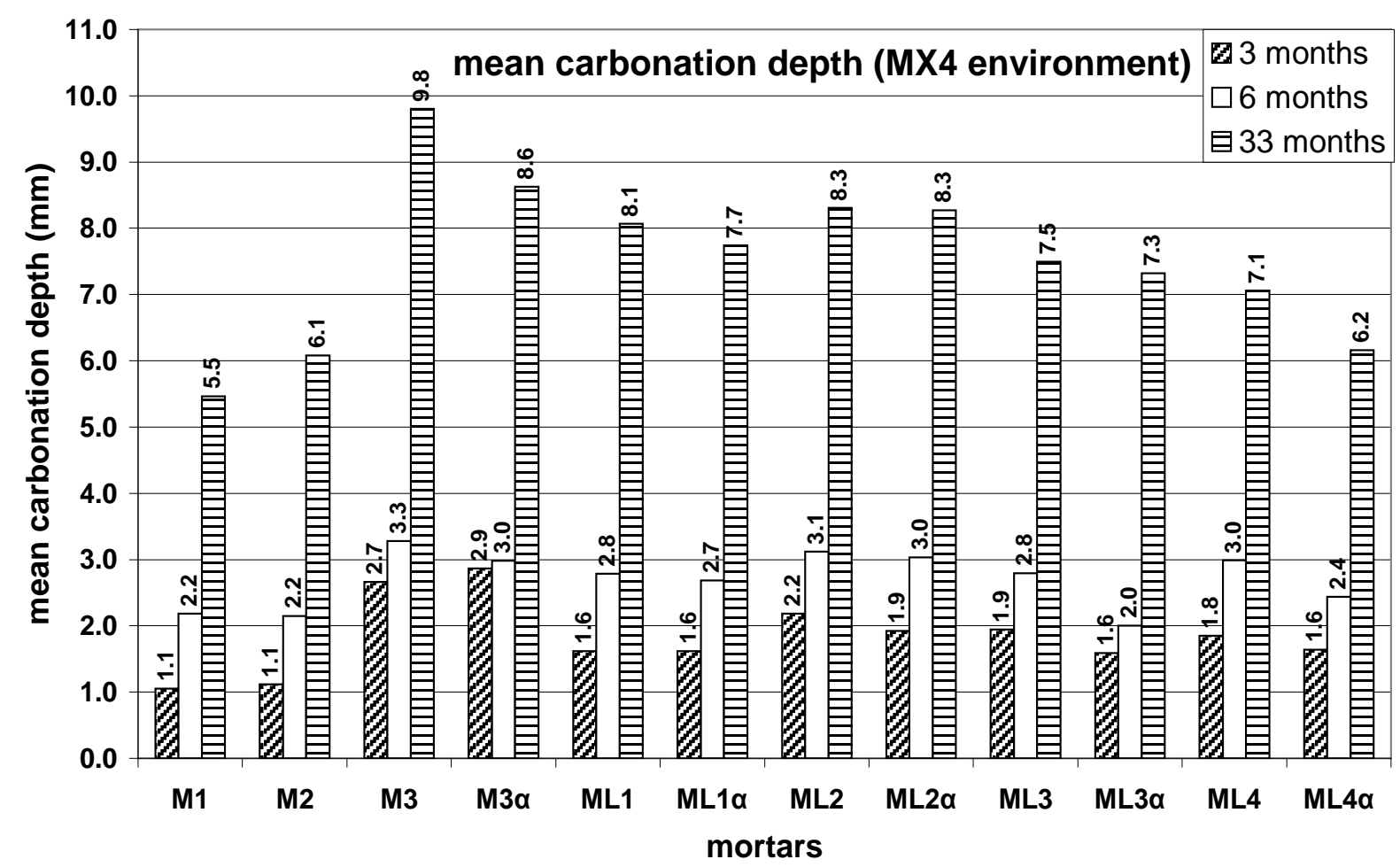

Figure 4. Mean carbonation depth at MX4 environment.

electrode (SCE). For this purpose, Cu wires were positioned at the protruding bars of all specimens. The whole procedure follows the directions of Standard ASTM C876-91 [20]. Figures 5-7 show the in-time development of the open circuit potential of the steel bar of the test mortars in the case of MX2 environment and plain steel, 


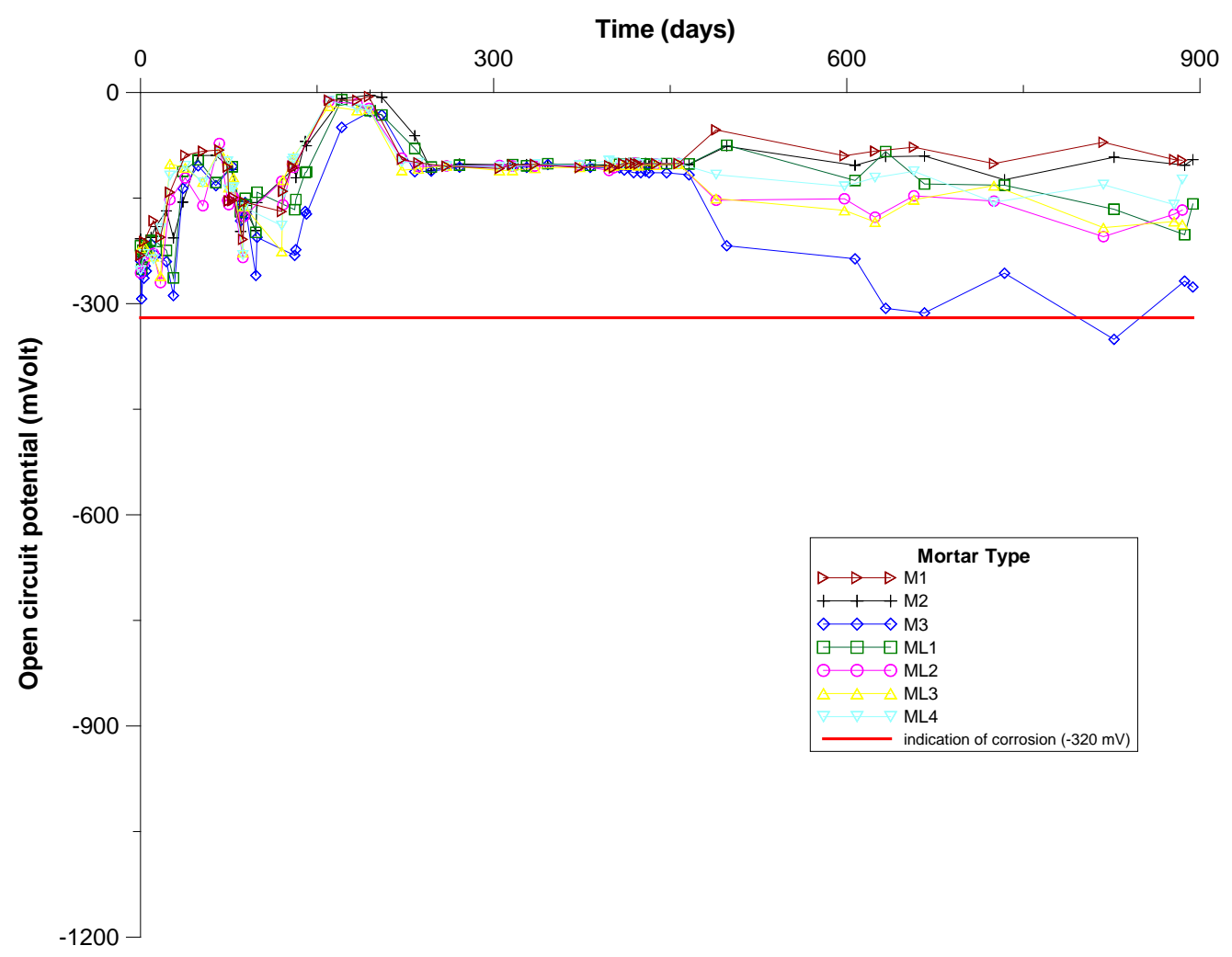

Figure 5. Development of open circuit potential for the MX2 environment and plain steel.

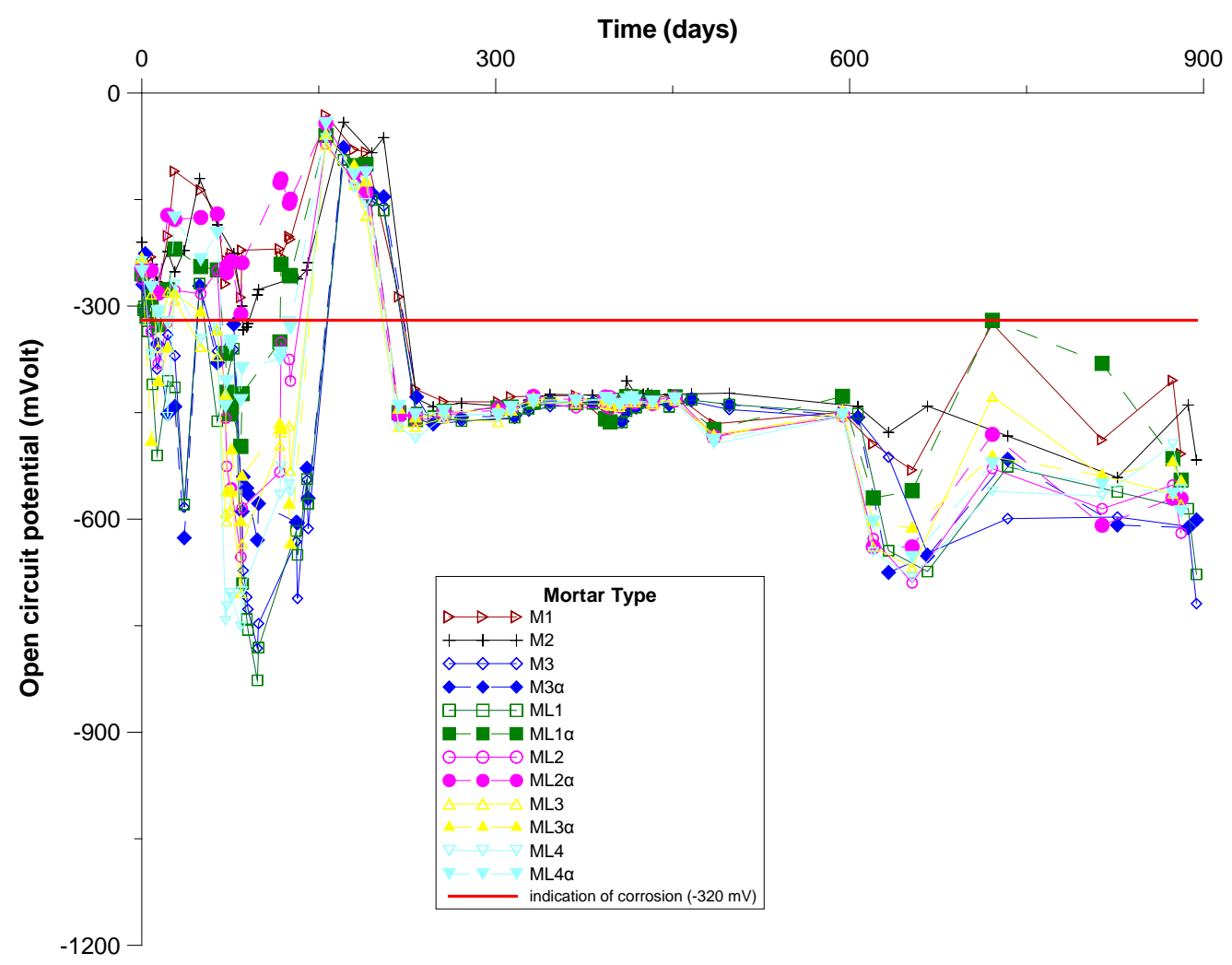

Figure 6. Development of open circuit potential for the MX4 environment and plain steel. 


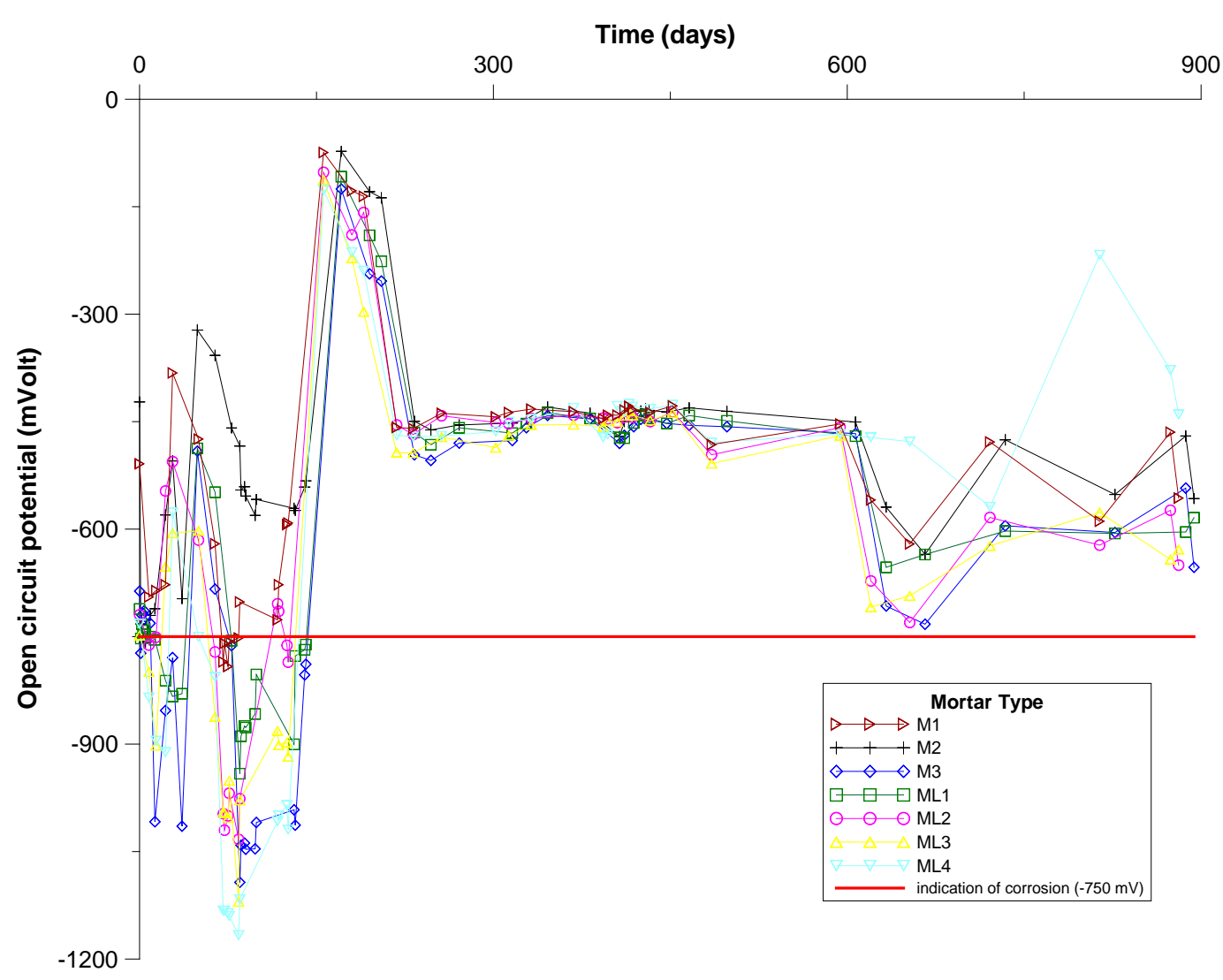

Figure 7. Development of open circuit potential for the MX4 environment and galvanized steel.

in the case of MX4 environment and plain steel and in the case of MX4 environment and galvanized steel respectively. It should be reminded that for plain steel more negative values of the potential than $-320 \mathrm{mVolts}$ suggests corrosion of the steel [21]. The respective value of galvanized steel is $-750 \mathrm{mVolts}$ [21].

Diagram 5 indicates that the open circuit potentials of the plain steel bars of all mortars in MX2 environment are quite similar regardless the type of mortar, and that potential remains well above -320 mVolts throughout the 33 months. This advocates that there is no sign of corrosion activity. However, it can be observed that after the first 500 days ( 18 months) the steel bars of the reference mortars (M1 and M2) seem to have more positive potentials.

On the contrary from diagram 6 one can observe that the values of the open circuit potentials of the plain steel bars of all mortars in MX4 environment are more negative than -320 mVolts throughout the 33 months, indicating that there is ongoing corrosion activity. The addition of sodium nitrite does not seem to alter the results.

The open circuit potential mean values of galvanized steel bars in all mortar compositions remain more positive than -750 mVolts, signifying that there is no corrosion. The more negative values which were observed throughout the first 100 days can be attributed to the formation/transformation of the passive protective layer on the surface of the bars [22].

\subsection{Mass Loss of Steel Bars}

Before the preparation of the specimens, the steel bars have been numbered and weighed with an accuracy of $0.0001 \mathrm{~g}$. After the ending of each period of time in the corrosive environment specimens are removed and split into two pieces parallel to the steel bar axis. Bars are taken away and weighed according to the Standard ISO/ DIS 8407.3 [23]. The final weight of the bars is again measured with an accuracy of 0.0001 gr. Figure 8 and Figure 9 depict the mean values of the mass loss (\%) of the plain steel bars for the period of 3, 6 and 33 months and for each type of mortar at corrosion environment MX2 and MX4 respectively, whereas Figure 10 depicts the same characteristics for the galvanized steel. 


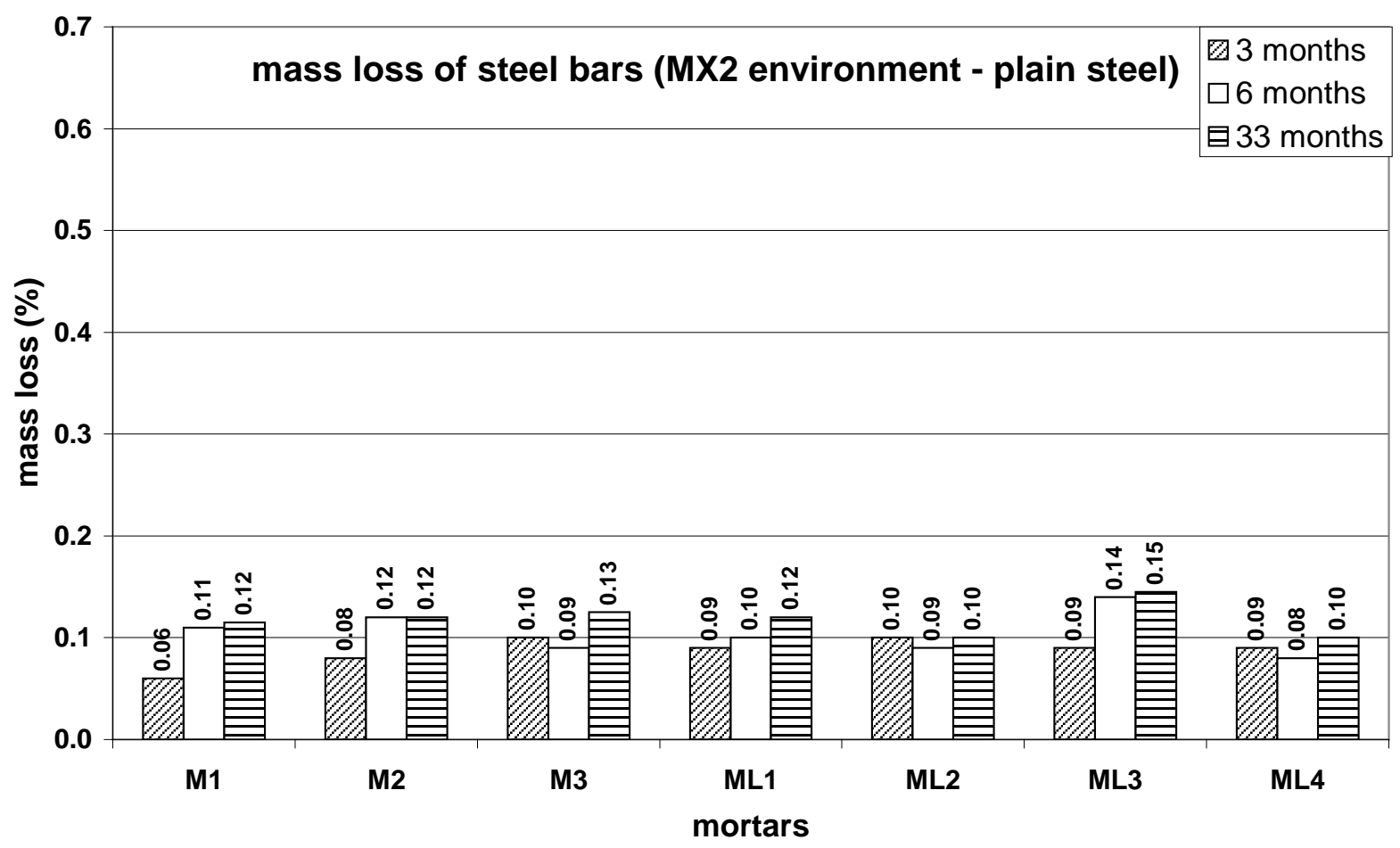

Figure 8. Mass loss of plain steel bars at MX2 environment.

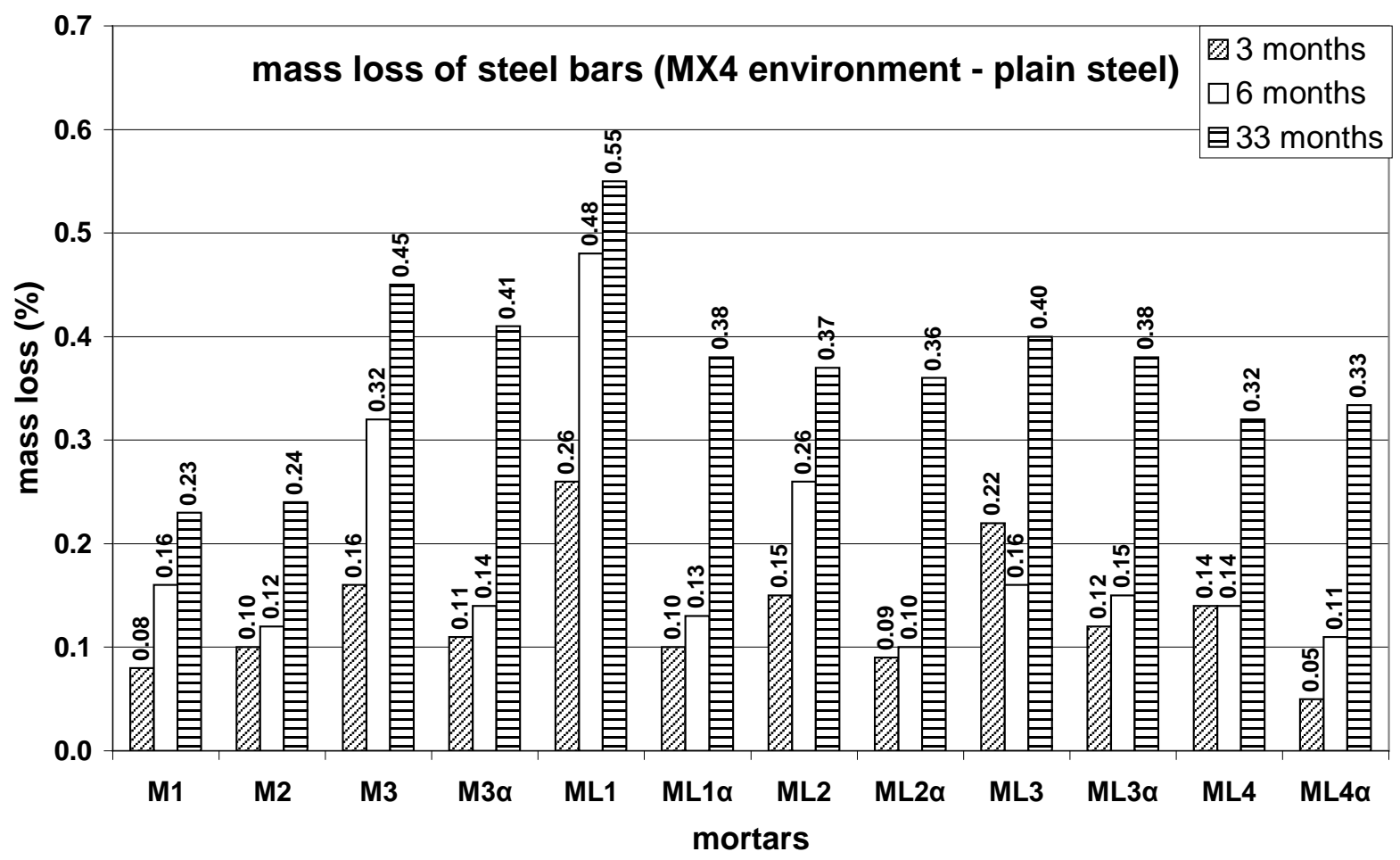

Figure 9. Mass loss of plain steel bars at MX4 environment.

Results indicate that for the first 3 months the mass loss of steel in all cases (types of mortars and types of steel) is insignificant; less than $\mathbf{0 . 1 0 \%}$. This mass loss of bars corresponds to the initial formation of the oxide protective layer on their surface due to the alkali environment of the paste surrounding them. 


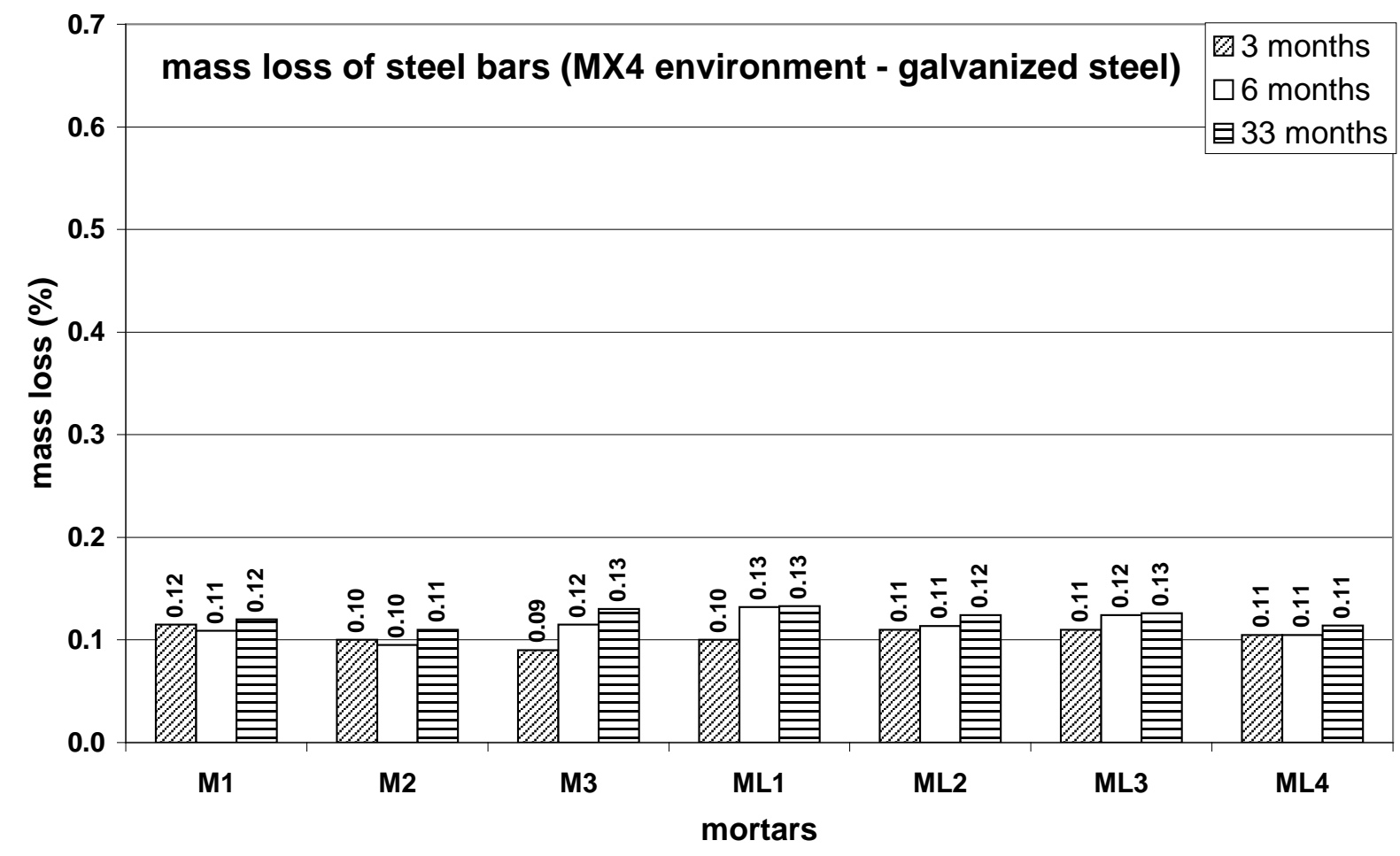

Figure 10. Mass loss of galvanized steel bars at MX4 environment.

In the case of MX2 environment, the mass loss of steel bars for all the examined types of mortars remains approximately stable and equal to the corresponding mass loss for the initial 3 months throughout the period of the 33 months, indicating that there in no further sign of corrosion.

In MX4 environment and in the case of plain steel bars, the results indicate that there is an increased mass loss for the period of the 33 months in all types of mortar; $40 \%-130 \%$ higher compared to MX2 environment. In MX4, mass loss of the two prototype mortars M1, M2 is $40 \%-80 \%$ lower than the mass loss of mortars M3, ML1, ML2, ML3, ML4.

The addition of sodium nitrite contributes to an improvement of the exhibited mass loss of steel only for the first 6 months. For this period of time the mass loss of steel remains the same as the initial mass loss of the first 3 months for all types of mortar. In the case of the 33 months, the mass loss of steel in mortars containing the corrosion inhibitor is $5 \%-20 \%$ lower than the respective mass loss in the same regular mortar compositions.

The galvanized steel bars (only in MX4 environment) do not show any signs of corrosion as the mass loss of steel for all the examined types of mortars throughout the period of 33 months remains stable, corresponding to the initial mass loss of the first 3 months. In general the time of exposure is small for the mass loss measurement.

\subsection{Presence of Chloride Ions}

Table 5 presents the quantities of chloride ions ( $\mathrm{gr}$ of $\mathrm{Cl}^{-}$per $\mathrm{m}^{3}$ of mortar) at the end of the 33 months.

Results indicate that in MX2 environment, all mortars contain very small amounts of $\mathrm{Cl}^{-}$; less than $70 \mathrm{gr} / \mathrm{m}^{3}$ ). Mortars M3, ML1, ML2, ML3, ML4 contain roughly three to four times more chloride ions than the prototype mortars.

The increase of the concentration of chlorides in mortars as a result increased the porosity.

In MX4 environment, $\mathrm{Cl}^{-}$quantities appear to be substantial; they are 20x the amounts found in MX2 environment. Again, mortars M3, ML1, ML2, ML3, ML4 contain roughly three to four times more chloride ions than the prototype mortars.

It is obvious that the amount of chlorides is little to accelerate the corrosion process. The difference of concentration between reference mortars (M1, M2 and M3) and the lime cement mortars is remarkable. 
Table 5. Concentration of chloride ions at 33 months $\left(\mathrm{g} / \mathrm{m}^{3}\right)$.

\begin{tabular}{ccc}
\hline & \multicolumn{3}{c}{$\mathbf{g r ~ C l}^{-} / \mathbf{m}^{3}$} & \\
Mortar & MX2 & MX4 \\
\cline { 2 - 3 } M2 & 7.0 & 150.5 \\
M3 & 24.0 & 400.2 \\
M3 $\alpha$ & 42.7 & 803.6 \\
ML1 & - & 762.7 \\
ML1 $\alpha$ & 40.7 & 840.8 \\
ML2 & - & 801.0 \\
ML2 $\alpha$ & 62.5 & 1280.8 \\
ML3 & - & 1230.5 \\
ML3 $\alpha$ & 64.9 & 1361.8 \\
ML4 & - & 1260.6 \\
ML4 $\alpha$ & 68.0 & 1310.7 \\
\hline
\end{tabular}

\section{Conclusions}

From the results reported in this paper it is concluded that:

- The five mortar compositions examined showed inferior durability behavior compared to the two prototype mortars, particularly in MX4 environment.

- Lime-cement mortars in low lime content are possible to exhibit similar properties against corrosion with pure cement mortars of the same sand and water proportions.

- The addition of anodic corrosion inhibitor (sodium nitrite) does not seem to essentially improve mortars' durability characteristics, but the time of exposure is relatively small.

- The optimum lime content in the mix in relation to the content of water and sand must further be studied.

- For masonry constructions in severe environments with high concentration of chloride ions, the use of protected-coated steel such as galvanized steel is suggested.

\section{Acknowledgements}

This research project is co-financed by E.U.-European Social Fund (80\%) and the Greek Ministry of Development-GSRT (20\%).

\section{References}

[1] Klingner, R.E. (2006) Behavior of Masonry in the Northridge (US) and Tecoman-Colina (Mexico) Earthquakes: Lessons Learned and Changes in US Design Provisions. Construction and Building Materials, 20, 209-219. http://dx.doi.org/10.1016/j.conbuildmat.2005.08.024

[2] Hidalgo, P.A., Chen Shy-Wen, J., Mayes, R.L., McNiven, H.D. and Clough, R.W. (1978) Cyclic Loading Tests of Masonry Single Piers-Volume 1, 2 \& 3. Earthquake Engineering Research Center. University of California. Berkeley. USA 1978-1979; Report No. UCB/EERC-78/28, 78/27 \& 79/12.

[3] Matsumura, A. (1988) Effectiveness of Shear Reinforcement in Fully Grouted Hollow Clay Masonry Walls. 4th Meeting of the US Japan Joint Technical Coordinating Committee on Masonry Research, San Diego, 17-19 October 1988, (620.3/J63/1988).

[4] Priestley, M.J.N. (1986) Seismic Design of Concrete Masonry Shear Walls. ACI Journal, 83, 58-68.

[5] Eurocode 8. Design of Structures for Earthquake Resistance, Section 5: Specific Rules for Masonry Buildings. CEN 2003. 
[6] Broomfield, J.P. (1994) Assessing Corrosion Damage on Reinforced Concrete Structures. Proceedings of Corrosion and Corrosion Protection of Steel in Concrete. International Conference, Sheffield, 24-28 July 1994, Volume 1, 1-25.

[7] Wheat, H.G. and Eliezer, Z. (1984) Some Electrochemical Aspects of Corrosion of Steel in Concrete. Corrosion NACE, 41, 640-645. http://dx.doi.org/10.5006/1.3582998

[8] Tassios, T.P. and Aligizaki, K. (1993) Durability of Reinforced Concrete. Fivos. Athens.

[9] Kouloumbi, N. and Batis, G. (1992) Chloride Corrosion of Steel Rebars in Mortars with Fly Ash Admixtures. Cement and Concrete Composites, 14, 199-207. http://dx.doi.org/10.1016/0958-9465(92)90014-M

[10] Kaci, A., Chaouche, M. and Andreani, P.-A. (2011) Influence of Bentonite Clay on the Rheological Behavior of Fresh Mortars. Cement and Concrete Research, 41, 373-379. http://dx.doi.org/10.1016/j.cemconres.2011.01.002

[11] Nunes, C. and Slizkova, Z. (2014) Hydrophobic Lime Based Mortars with Linseed Oil: Characterization and Durability Assessment. Cement and Concrete Research, 61-62, 28-29. http://dx.doi.org/10.1016/j.cemconres.2014.03.011

[12] Batis, G. and Psila, N. (1996) Durability of Reinforced Masonry Mortars in Corrosive Environment with and without Chloride Ions. 12th Hellenic Concrete Conference, 1, 159-166.

[13] Batis, G., Kouloumbi, N. and Katsiamboulas, A. (1996) Durability of Reinforced Lightweight Mortars with Corrosion Inhibitors. Cement, Concrete and Aggregates, 18, 118-125.

[14] EN 998: Specification for Mortar for Masonry. Part 2: Masonry Mortar. CEN 2001.

[15] Eurocode 6. Design of Masonry Structures. Part 1-1: General Rules for Buildings-Rules for Reinforced and Unreinforced Masonry. CEN 2003.

[16] Mira, P., Papadakis, V.G. and Tsimas, S. (2001) Effect of Lime Putty Addition on Structural and Durability Properties of Concrete. Cement and Concrete Research, 32, 683-689. http://dx.doi.org/10.1016/S0008-8846(01)00744-X

[17] EN 1015. Methods of Test for Mortar for Masonry. Part 2: Sampling of Mortars and Preparation of Test Mortars. CEN 1998.

[18] EN 197-1. Cement Compositions, Specifications and Conformity Criteria for Common Cements. CEN 2001.

[19] EN 1015. Methods of Test for Mortar for Masonry. Part 11: Determination of Flexural and Compressive Strength of Hardened Mortars. CEN 1998.

[20] ASTM C876-91. Test Method for Half-Cell Potentials of Uncoated Reinforcing Steel in Concrete.

[21] Carino, N.J. (1999) Nondestructive Techniques to Investigate Corrosion Status in Concrete Structures. Journal of Performance of Constructed Facilities, 13, 96-106. http://dx.doi.org/10.1061/(ASCE)0887-3828(1999)13:3(96)

[22] Roventi, G., Bellezze, T., Barbaresi, E. and Fratesi, R. (2013) Effect of Carbonation Process on Passivating Products of Zinc in $\mathrm{Ca}(\mathrm{OH})_{2}$ Saturated Solution. Materials and Corrosion, 64, 1007-1014.

[23] ISO/DIS 8407.3. Metals and Alloys-Procedures for Removal of Corrosion Products from Corrosion Test Specimens. 